\title{
Surgical Treatment of a Case of
Tracheobronchopathia
Osteochondroplastica with a Thymic Cyst
} Timik Kistin Esslik Ettiği Trakeobronkopati Osteokondroplastika Olgusunda
Cerrahi Tedavi

Kenan Can Ceylan, Hüseyin Mestan, Şeyda Örs Kaya

\section{Abstract}

Tracheobronchopathia osteochondroplastica is a rare benign disease that is characterized by multiple submucosal osseous and cartilaginous nodules in the tracheal bronchus. The etiology is not clear. A thoracic computed tomography of a 75 year-old female patient with complaints of dyspnea and cough for a year revealed two different lesions on the trachea and the anterior mediastinum. A bronchoscopy revealed a solid mass in the distal part of the trachea, affecting 4-5 cartilaginous rings and restricting the tracheal lumen by approximately $70 \%$. The mass was located approximately two cartilaginous rings distant to the carina. A tracheal sleeve resection and thymectomy were performed through a right thoracotomy. The histopathological results indicated tracheobronchopathia osteochondroplastica and a thymic cyst. The postoperative follow up was uneventful. We report this rare case since the co-existence of tracheobronchopathia osteochondroplastica and the thymic cyst is a condition rarely seen in literature.

Key words: Surgery, thymic cyst, Tracheobronchopathia Osteochondroplastica.

\section{Özet}

Trakeabronkopatia osteokondroplastika nadir görülen, trakea ve bronş lümenine doğru çıkıntı yapan çok sayıda osseöz ve kartilajönez nodüller ile karakterize benign bir hastalıktır. Etyolojisi belli değildir. Yetmiş beş yaşında kadın hastaya bir yıldır devam eden dispne ve öksürük şikâyeti nedeni ile çekilen toraks bilgisayarlı tomografide trakea ve anterior mediastende kitle saptandı. Bronkoskopide trakeada yaklaşık 4-5 kıkırdak halka kadar ilerleyen, lümeni \%70' ye yakın daraltan kitle lezyonu görüldü. Distalinde karinaya yaklaşık 2 kıkırdak halka mesafe yerleşimliydi. Hastaya sağ torakotomi ile trakeal sleeve rezeksiyon ile uç uca anastomoz ve timektomi operasyonu uyguland. Histopatolojik incelemelerin sonucu trakeabronkopatia osteokondroplastika ve timik kist ile uyumlu olarak değerlendirildi. Postoperatif dönemde kompikasyon gelişmedi. Olgu trakeabronkopatia osteokondroplastika ve timik kist birlikteliği çok nadir görüldüğü için sunulmuştur.

Anahtar Sözcükler: Cerrahi, timik kist, Trakeabronkopatia Osteokondroplastika.
Department of Thoracic Surgery, Dr. Suat Seren Chest Disease and Thoracic Surgery Training and Research Hospital, İzmir, Turkey
Dr. Suat Seren Göğüs Hastalıkları ve Cerrahisi Eğitim ve Araştırma Hastanesi- Göğüs Cerrahisi Kliniği, İzmir

Submitted (Başvuru tarihi): 03.03.2020 Accepted (Kabul tarihi): 28.04.2020

Correspondence (iletişim): Kenan Can Ceylan, Department of Thoracic Surgery, Dr. Suat Seren Chest Disease and Thoracic Surgery Training and Research Hospital, İmir, Turkey

e-mail: kcanceylan@gmail.com 
Tracheobronchopathia Osteochondroplastica (TO) is a rare benign disease characterized by multiple osseous and cartilaginous nodules that protrude into the tracheal and bronchial lumen. The etiology of the disease is not clear. The disease usually presents as multiple lesions in the trachea, but can rarely manifest as a single lesion in the peripheral bronchi. Patients are usually asymptomatic. Chronic cough, wheezing, dyspnea and hemoptysis may be seen in symptomatic patients. Atelectasis and obstructive pneumonitis may develop recurrent respiratory infections, requiring surgical treatment or bronchoscopic management when a conservative treatment such as bronchodilators and antibiotics fails. A case of tracheobronchopathia osteochondroplastica accompanied by a thymic cyst is presented in the light of literature due to its rarity.

\section{CASE}

A 75 year-old female patient was examined with complaints of dyspnea and cough for one year. Thoracic computed tomography (CT) revealed nodules in the trachea and a mass lesion on the anterior mediastinum, 6 $\mathrm{cm}$ in diameter (Figure $1 \mathrm{~A}$ and B). A Positron Emission Tomography CT evaluation showed no $18 \mathrm{~F}$ - fluorodeoxyglucose (FDG) uptake in the tracheal lesions, while a low 18F-FDG (standard uptake value: 1.3) uptake was observed in the anterior mediastinal mass. The patient had a history of type 2 diabetes mellitus, hypertension and coronary stenting due to coronary artery disease. There was no smoking history, and her forced expiratory volume (FEVI) was $1.49 \mathrm{~L}$ (73\%), forced vital capacity (FVC) $1.70 \mathrm{~L}(69 \%)$ and $\mathrm{FEV} 1 / \mathrm{FVC}$ ratio $87 \%$. A rigid bronchoscopy revealed intraluminal nodules that progressed to approximately four to five cartilage rings and obstructed the lumen to $70 \%$. Nodules were located on approximately two cartilaginous rings distant to the carina. No Myasthenia Gravis was detected in a preoperative neurology consultation. A tracheal segmental resection and anastomosis with maximal thymectomy operation via the right thoracotomy were performed. The performance of a right thoracotomy on the fourth intercostal space was helpful in controlling both the distal part of the trachea and the anterior mediastinum. The exact localization of tracheal lesion was ascertained from a preoperative bronchoscopy. The length of the intratracheal lesion was approximately $2.5 \mathrm{~cm}$. A continuous $3 / 0$ prolene suture technique was used for tracheal anastomosis. A microscopic examination of the tracheal nodules revealed subepithelial macrophage deposition, nodular development involving calcification, and ossification in the submucosa, whereupon the patient was diagnosed with tracheobronchopathia osteochondroplastica (Figure 2). A pathological examination of the mediastinal mass revealed it to be a simple thymic cyst. Bronchoscopy was performed for postoperative control, and the anastomosis line of the tracheal segmental resection and lumen diameters were evaluated as standard. The patient was discharged without event. Follow-up included an annual thorax $\mathrm{CT}$, and the patient is now in the 33rd month of clinical follow-up without disease, and with no recurrence noted to date.
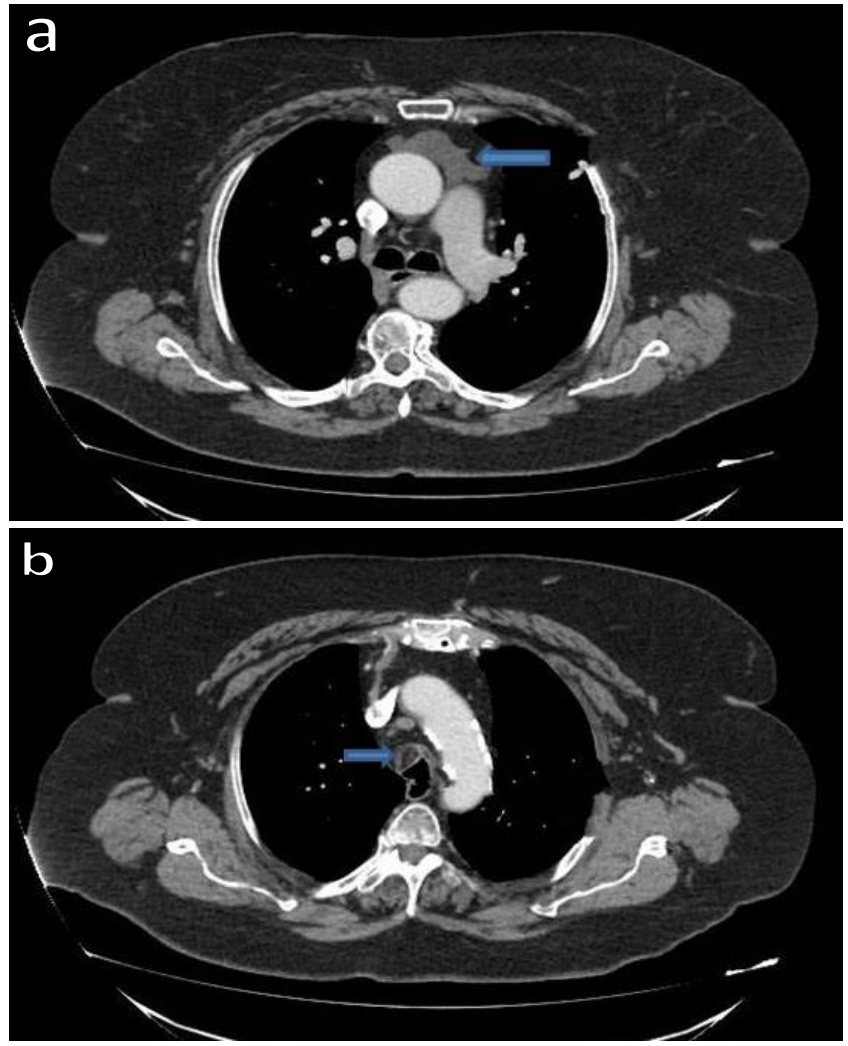

Figure la and b: $C T$ view of the mediastinal mass (A), CT view of the tracheal lesion (B)

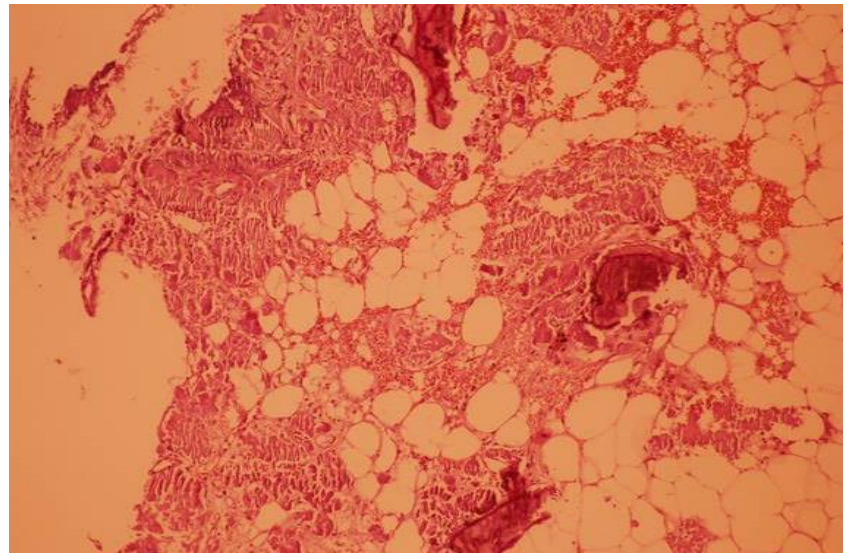

Figure 2: Microscopic view of the TO (H\&E x100) 


\section{DISCUSSION}

TO is a benign, rare disease that is characterized by multiple submucosal osseous and cartilaginous nodules involving the anterior and lateral walls of the trachea and the bronchial tree. The posterior membrane part of the trachea is typically unaffected by the disease, which was first described by Rokitansky in 1855, then by Luschka in 1856 and Wilks in 1857 (1). The actual incidence is higher than the reported cases, as the disease is generally asymptomatic. Symptomatic cases present with such nonspecific symptoms as cough, wheezing and hemoptysis (2). In symptomatic patients, the symptoms are related to complicated pulmonary infections, leading to trache$\mathrm{al} /$ bronchial obstructions and dyspnea. There is an average of 4 years between the onset of symptoms and the diagnosis of disease.

In asymptomatic patients, the disease is diagnosed incidentally during bronchoscopy or radiological examinations for other pulmonary pathologies. Thorax CT may show diffuse submucosal calcific nodules protruding from the anterolateral wall of the trachea into the lumen. Chest radiographs usually reveal no pathology. The optimum approach to the diagnosis of TO is bronchoscopy, in which it is typical to observe white-colored irregular multiple nodules on the 2/3 lower part of the trachea involving the anterior and lateral walls. Women and men are equally affected by $\mathrm{TO}$, which is usually observed in the fourth and seventh decades (3), although several cases have been reported in children and young adults (4-6). Our case was an elderly woman with dyspnea, in which a thoracic CT performed due to the symptoms of the patient showed intratracheal lesions and a mass measuring $6 \mathrm{~cm}$ in diameter in the anterior mediastinum. A rigid bronchoscopy revealed tracheal nodules that constricted the lumen of the trachea by $70 \%$, and the patient was diagnosed with tracheobronchopathia osteochondroplastica following biopsy.

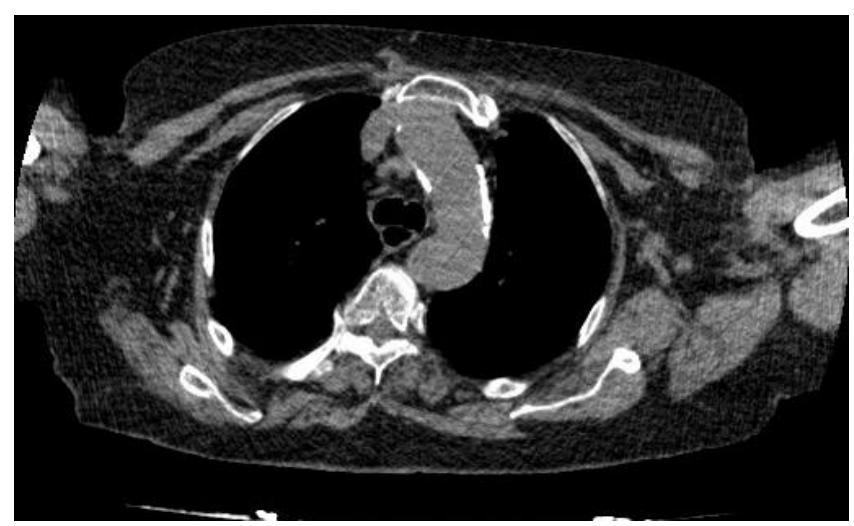

Figure 3: Postoperative CT image
TO may also present in the larynx and may be one of the causes of difficult intubation (7), and may be accompanied by diseases such as thyroid tumor, thymoma, atrophic rhinitis, lymphoma and epidermal cyst $(8,9)$. In our case, TO was accompanied by a thymic cyst, which are rare benign lesions of the mediastinum that are usually located in the anterior compartment. These lesions account for approximately $3 \%$ of all anterior mediastinal masses (10), and may be congenital or acquired. Factors such as trauma, inflammatory disease, previous surgical operations and radiation have been reported among the acquired causes (11). Thymic cysts are most commonly seen between the ages of 20 and 50 years, and are usually asymptomatic. Complaints may be related to the location and size of the lesion, leading to cough, shortness of breath and chest pain in symptomatic patients.

Despite intraluminal nodules, pulmonary lung function is generally preserved. In the present case, the pulmonary function test results were FEVI 1.49 L (73\%), FVC 1.70 L $(69 \%)$ and $\mathrm{FEV} 1 / \mathrm{FVC}$ ratio $87 \%$. Arterial blood gas indicated partial oxygen pressure of $90 \mathrm{mmHg}$, partial carbon dioxide $42 \mathrm{mmHg}, \mathrm{pH} 7.43$ and saturation $95 \%$.

No specific treatment has been defined for TO. Conservative treatment approaches may be applied in asymptomatic patients with no severe obstructions. In patients with airway obstructions, bronchoscopic treatment procedures and surgery are the options, selected according to the patients (12). Laser approaches provide the opportunity to obtain either fragmentations or indentations of nodules, which makes it easier to debulk from the submucosa mechanically by rigid bronchoscopy. A combination of laser treatment with stents can improve treatment success. Radiation therapy is the other option for the relief of symptoms. A surgical resection of the TO may be chosen in cases of localized disease and severe airway obstruction. The success of bronchoscopic treatments depends on the method used, such as neodymium-doped yttrium aluminum garnet laser ablation, cryotherapy or cauterization, although the results of laser ablation are superior. On the other hand, hard, debulking bony lesions may prove to be challenging with rigid bronchoscopy. The patient in the present had been suffering from deep dyspnea with effort and cough for one year, despite a year of medical treatment. Mediastinal mass compression may also explain dyspnea. Considering these factors, we prefer surgical treatment.

Surgical treatments of thymic cysts should be performed due to the likelihood of the disease leading to such complications as pneumothorax, dysphagia, vocal cord paral- 
ysis, Horner syndrome and the potential to develop into thymic carcinoma over time (13).

TO progresses slowly, and prognosis is favorable. The patient in the present study developed no symptoms during the postoperative follow-up period of 33 months, similar to the findings reported in literature.

In conclusion, the co-existence of $\mathrm{TO}$ and thymic cyst is a very rare and benign condition, and is usually asymptomatic. Surgical treatment should be kept in mind in appropriate symptomatic cases. Patients with extensive lesions should be treated via bronchoscopic procedures, while conservative treatment can help relieve symptoms.

\section{CONFLICTS OF INTEREST}

None declared.

\section{AUTHOR CONTRIBUTIONS}

Concept - K.C.C., H.M., S.Ö.K.; Planning and Design K.C.C., H.M., S.Ö.K.; Supervision - K.C.C., H.M., S..̈.K.; Funding -; Materials - H.M.; Data Collection and/or Processing - H.M.; Analysis and/or Interpretation K.C.C., H.M., Ş.Ö.K.; Literature Review - K.C.C., H.M.; Writing - K.C.C., H.M.; Critical Review - H.M., K.C.C., S.Ö.K.

\section{YAZAR KATKILARI}

Fikir - K.C.C., H.M., S.Ö.K.; Tasarım ve Dizayn - K.C.C., H.M., Ş.Ö.K.; Denetleme - K.C.C., H.M., Ş.Ö.K.; Kaynaklar -; Malzemeler - H.M.; Veri Toplama ve/veya İşleme - H.M.; Analiz ve/veya Yorum - K.C.C., H.M., Ş.Ö.K.; Literatür Taraması - K.C.C., H.M.; Yazıyı Yazan - K.C.C., H.M.; Eleştirel İnceleme - H.M., K.C.C., Ş.Ö.K.

\section{REFERENCES}

1. Baha A, Körlü T, Köktürk N, Türktaş H. Tracheobronchopatia Ostecondroplastica: two cases studies. Respir Case Rep 2014; 3:1-5. [CrossRefl

2. Ulasli SS, Kupeli E. Tracheobronchopathia osteochondroplastica: a review of the literature. Clin Respir J 2015; 9:386-91. [CrossRef]
3. Lazor R, Cordier JF. Tracheobronchopathia osteochondroplastica. Orphanet Encyclopedia 2004.

4. Jindal S, Nath A, Neyaz Z, Jaiswal S. Tracheobronchopathia osteochondroplastica-a rare or an overlooked entity? J Radiol Case Rep 2013; 7:16-25. [CrossRef]

5. Sant'Anna CC, Pires-de-Mello P, de Fátima Morgado $M$, March MdFP. Tracheobronchopathia osteochondroplastica in a 5-year-old girl. Indian Pediatr 2012; 49:985-6. [CrossRef]

6. Swamy T, Hasan A. Tracheopathia osteoplastica presenting with haemoptysis in a young male. Indian J Chest Dis Allied Sci 2010; 52:119-21.

7. Warner MA, Chestnut DH, Thompson G, Bottcher M, Tobert D, Nofftz M. Tracheobronchopathia osteochondroplastica and difficult intubation: case report and perioperative recommendations for anesthesiologists. J Clin Anesth 2013; 25:659-61. [CrossRef]

8. Karlikaya C, Yüksel M, Kiliçli S, Candan L. Tracheobronchopathia osteochondroplastica. Respirology 2000; 5:377-80. [CrossRef]

9. Meyer C, Døssing M, Broholm H. Tracheobronchopathia osteochondroplastica. Respir Med 1997; 91:499-502. [CrossRef]

10. Fujiwara T, Mizobuchi T, Noro M, Iwai N. Rapid enlargement of a mediastinal mass: thymoma hemorrhage into a thymic cyst. Gen Thorac Cardiovasc Surg 2008; 56:472-5. [CrossRef]

11. Kim JH, Goo JM, Lee HJ, Chung MJ, Jung SI, Lim KY, et al. Cystic tumors in the anterior mediastinum: radiologicpathological correlation. J Comput Assist Tomogr 2003; 27:714-23. [CrossRef]

12. Şenguil AT, Büyükarabacak Y, Apaydın T, Bassoglu A, SullüY. Tracheobronchopatia osteochondroplastica case resulting with big airway obstruction. J Exp Clin Med 2018; 35:81-3. [CrossRef]

13. Leong AS, Brown JH. Malignant transformation in a thymic cyst. Am J Surg Pathol 1984; 8:471-5. [CrossRef] 